\title{
IMPLEMENTATION OF MODULAR TRUCKS INTO ROAD TRANSPORT
}

\section{KONCEPCJA WDROŻENIA ZESPOLÓW MODULOWYCH W TRANSPORCIE DROGOWYM}

\author{
Lukasz Muślewski ${ }^{1)}$, Bogdan Landowski ${ }^{1)}$, Maciej Woropay ${ }^{2)}$, \\ Klaudiusz Migawa ${ }^{1)}$ \\ ${ }^{1)}$ University of Science and Technology, Bydgoszcz, Poland \\ ${ }^{2)}$ University of Bydgoszcz, Poland
}

\begin{abstract}
In this article, an analysis of modular truck application in the road transport in Poland has been made. Terminology has been unified. Classification and law regulations applicable in different European countries and all over the world have been discussed. An analysis of existing solutions has been made and an optimal variant for road freight transport, including the condition and parameters of the road infrastructure in Poland, has been proposed. The study presents initial conceptual assumptions of this project as well as advisability of using these modular trucks, on the basis of a selected research object - the analyzed transport company. On this example, an analysis of costs and potential profits to be generated from transport services performed using the proposed modular trucks and with reference to costs borne by the investigated company with the use of currently operated transport means, has been made.
\end{abstract}

Keywords: road transport, modular trucks, efficiency, costs of operation

Streszczenie: $W$ niniejszym artykule zrealizowano analize $i$ ocene zastosowania systemów modułowych $w$ transporcie drogowym w Polsce. Dokonano ujednolicenia terminologii, klasyfikacji oraz uwarunkowań prawnych obowiazujacych $w$ innych krajach europejskich $i$ na świecie. W pracy dokonano analizy funkcjonujacych rozwiazań i zaproponowano wybór optymalnego wariantu dla samochodowego transportu towarowego w Polsce, z uwzględnieniem stanu i parametrów krajowej infrastruktury drogowej. W opracowaniu opisano wstępne założenia koncepcyjne w tym obszarze, jak również dokonano analizy celowości zastosowania niniejszych zestawów modułowych na przykładzie wybranego obiektu badań - analizowanego przedsiebiorstwa transportowego, stanowiacego obiekt badań. Na jego przykładzie dokonano analizy kosztów i szacunkowych zysków $z$ realizowanych procesów transportowych, z wykorzystaniem proponowanych zespołów modułowych, $w$ odniesieniu do kosztów ponoszonych przez badane przedsiębiorstwo $z$ zastosowaniem obecnie eksploatowanych środków transportowych.

Slowa kluczowe: transport drogowy, zestawy modulowe, efektywność, koszty eksploatacji 
Implementation of modular trucks into road transport

Koncepcja wdrożenia zespołów modułowych $w$ transporcie drogowym

\section{Introduction}

Load capacity of vehicles is a functional quality significant in transport of loads with relatively high density. It is limited by administrative regulations on the maximum authorized weight of vehicles. The major legal act which regulates parameters of vehicles authorized to run on the roads of the European Union is Directive 96/53. It imposes limitation on the total weight of vehicles to be 40 tones and length of the modular truck to e b18.75m. However, it needs to be emphasized that each country has the possibility to introduce departures from this Directive. Allowing longer and heavier vehicles to run the roads only on the territory of one's own country is possible in reference to the so called modular concept of transport and without violation of competition rules in the transport sector. The number of countries which decided to introduce departures of this kind is constantly increasing and the leaders of such implementations are Scandinavian countries. Having in mind general benefits and threats related to such solutions the authors of this study have made an analysis of possibilities and advisability of implementation of road transport modular trucks into the Polish road transport

\section{Analysis of types of modular road trucks used in the world}

Transport of loads by vehicles longer and heavier than the standard ones is connected with the problems of inter-branch competition in transport. Comparing the European Union road transport with the road transport of the North America, Australia or North Asia it is easy to notice its specificity [22-25]. Europe is a much more populated continent with very dense road infrastructure characterized by many restrictions related to technical road parameters [7]. However, the purpose of increasing load capacity of trucks is of key importance in terms of effective competition with railroad and water transport. Each cubic meter or tone of cargo to be placed in the truck means reduction of transport unit costs, and these costs have always been in favor of railroad and ships. During the last half century the authorized maximum weight of vehicles has increased from 10 to 30 tons, that is even by $50 \%$ [4]. This was possible due to such solutions as the so called 'modular transport concept", which provides the possibility of replacing an oversize vehicle or combination vehicles with an oversize truck train built from vehicles, semitrailers or trailers that comply with the norms. In other words, a member state of the EU allowing use of vehicles longer than those indicated in the Directive has also to give permission for use of longer road trains built from modules (vehicles, trailers or semi-trailers) which comply with the norms. Many countries have taken advantage of the possibility of using these departures which is reflected by the data from table 1 [7]. 
Łukasz Muślewski, Bogdan Landowski, Maciej Woropay, Klaudiusz Migawa

Tab.1 Maximum vehicle weights and dimensions in selected countries of the European Union [7].

\begin{tabular}{|c|c|c|c|c|c|}
\hline \multirow[b]{2}{*}{ Country } & \multirow{2}{*}{$\begin{array}{c}\text { Vehicle } \\
\text { maximum total } \\
\text { weight }[\mathrm{t}]\end{array}$} & \multirow[b]{2}{*}{ Height [m] } & \multirow[b]{2}{*}{ Width [m] } & \multicolumn{2}{|c|}{ Length [m] } \\
\hline & & & & $\begin{array}{l}\text { Articulated } \\
\text { vehicle }\end{array}$ & Road train \\
\hline 96/53 Directive & 40.00 & 4.00 & 2.55 & 16.50 & 18.75 \\
\hline Belgium & 44.00 & 4.00 & 2.55 & 16.50 & 18.75 \\
\hline Czech & 48.00 & 4.00 & 2.50 & 16.50 & 18.75 \\
\hline Denmark & 48.00 & 4.00 & 2.55 & 16.50 & 18.75 \\
\hline Finland & 60.00 & 4.20 & 2.60 & 16.50 & 25.25 \\
\hline France & 40.00 & Not specified & 2.55 & 16.50 & 18.75 \\
\hline Holland & 50.00 & \begin{tabular}{l|}
4.00 \\
\end{tabular} & 2.55 & 16.50 & 18.75 \\
\hline Ireland & 44.00 & 4.00 & 2.55 & 16.50 & 18.75 \\
\hline Luxemburg & 44.00 & 4.00 & 2.55 & 16.50 & 18.75 \\
\hline Germany & 40.00 & 4.00 & 2.60 & 16.50 & 18.75 \\
\hline Poland & 40.00 & 4.00 & 2.60 & 16.50 & 18.75 \\
\hline Sweden & 60.00 & Not specified & 2.55 & 25.25 & 24.00 \\
\hline Great Britain & 44.00 & Not specified & 2.55 & 16.50 & 18.75 \\
\hline Italy & 44.00 & 4.00 & 2.55 & 16.50 & 18.75 \\
\hline
\end{tabular}

In different countries and on different discussion forums such vehicles are referred to as: Gigaliners, Megatrucks, Jumbotrucks, Monstertrucks, Longer and Heavier Vehicles (LHV), EuroCombi, Öko-Kombis, European Modular System (EMS) [3,7-9,17-21]. These truck trains are formed from standard vehicles such as:

- truck tractors (module A),

- $13.6 \mathrm{~m}$ long two or three axle (module B),

- $7.82 \mathrm{~m}$ long two or three axle trailers with the axle central location (module C),

- three axle semi-trailer with special structure (module D),

- three or four axle truck (module E),

- three axle trailers (module F),

- two axle with the so called 'dolly' (module G) [1].

The above listed modules are components of differently combined vehicles. There are five configurations of truck trains (figure 1) [7]:
a) $\mathrm{A}+\mathrm{B}+\mathrm{C}$
b) $\mathrm{A}+\mathrm{D}+\mathrm{B}$,
c) $\mathrm{E}+\mathrm{F}$,
d) $\mathrm{E}+\mathrm{G}+\mathrm{B}$
e) $\mathrm{E}+\mathrm{C}+\mathrm{C}$.

Their graphic representation is as follows: 
Implementation of modular trucks into road transport

a)

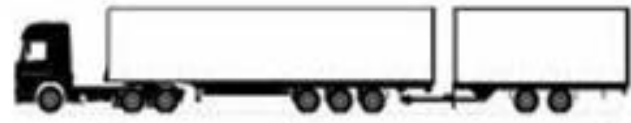

b)

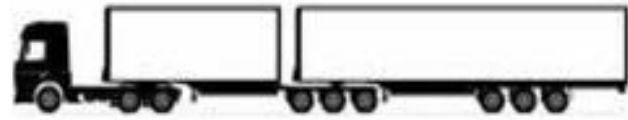

c)

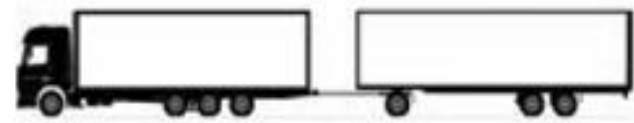

d)

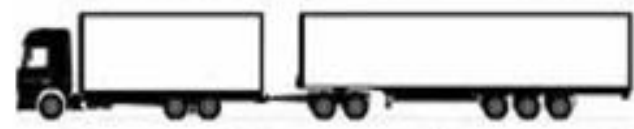

e)

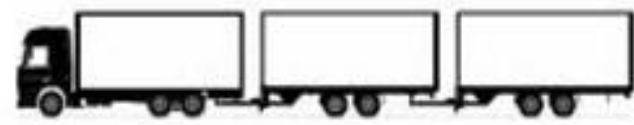

Fig.1 The most commonly used solutions of truck trains in Europe [7]

However, when it comes to the worldwide transport it needs to be stressed that the largest road trains are used in Australia (the largest and heaviest vehicles allowed to move on the roads whose weight approaches 200t.), Canada, USA and Mexico. Road trains are used for transport of all kinds of cargo including livestock, fuel, mineral ores and package cargo and their cost efficiency has largely contributed to economic development of more distant regions.

\section{Infrastructural aspects of road modular trucks in Poland}

According to the function, Polish roads are divided into the following categories:

a) national roads (class A, S, GP, exceptionally G),

b) province roads (class $\mathrm{G}, \mathrm{Z}$, exceptionally GP),

c) district roads (class G, Z, exceptionally L),

d) local roads (class L, D, exceptionally Z) [12].

Maximum authorized load of a single axle on the surface of a given class road are presented in table 2 .

Tab. 2. Maximum authorized load of the vehicle axle on the road surface [12].

\begin{tabular}{|l|l|}
\hline Road class & Authorized vehicle axle load (t) \\
\hline A, S & 11.5 \\
\hline GP & $11.5,10^{*}$ \\
\hline G, Z, L, D & $10,8^{*}$ \\
\hline
\end{tabular}

Permitted during road resurface or maintenance works.

On national roads the maximum authorized axle load can differ from section to section. In Poland such a road is, e.g. DK5. Due to the dimensions and total authorized weight, EMS would move only on the main roads, that is freeways, expressways and national ways. 
In connection with an increased number axles, the load they exert is similar to standard trucks. Road modular trucks with total authorized weight up to 60t, with 7 axles exert load close to $8.57 \mathrm{t}$ per one axle. Comparing this value with the load exerted on the axle by standard trucks the difference is small. In a DCM 40 truck with five axles, the mean load on one axle is 8t. Therefore, from the point of view of the axle load, EMS could be authorized to run on the main roads. Other elements of road infrastructure in Poland, which theoretically could be an obstacle to implementation of EMS are bridges and viaducts. Increasing the authorized maximum weight of trucks would not have a negative influence on infrastructure of these objects as in this case this is also the axle load which is the main indicator. If the weight was properly distributed on particular axles such a truck would not pose a threat to the above mentioned structures. It is worth noticing that oversize transport means whose total weight significantly exceeds $40 t$ already move on structures like that and they cause no damage to them [6].

The biggest problem for the Polish road infrastructure to be solved after implementation of EMS into the road traffic are crossroads and roundabouts. Currently, $16.5 \mathrm{~m}$ and $18.75 \mathrm{~m}$ long standard trucks have problems to go through crossroads as the turn radius of sewered entries of class G, GP, Z and D roads is $10 \mathrm{~m}$, and for unsewered entries of class $\mathrm{G}$ and $\mathrm{Z}$ roads is $8 \mathrm{~m}$ [12].

However, according to the rules of unsewered crossroads, $16.5 \mathrm{~m}, 18.75 \mathrm{~m}$ and $25.25 \mathrm{~m}$ long vehicles equipped with turning axles with minimum turning radius is $12.5 \mathrm{~m}$ and $14.5 \mathrm{~m}$ can go through each crossroad which have drive-in isles. The only obstacle for $25.25 \mathrm{~m}$ long vehicles are sewered crossroads without drive-in isles. On the national roads the crossroads of this type occur rarely but it is recommended to restructure them. A 'dolly' truck whose turning system is active is a good solution for trucks with turning axles. Thanks to this the EMS have no difficulty to go through crossroads as such a system makes the truck train drift away along the inner radius by about $5.3 \mathrm{~m}$ whereas the semi-trailer follows smoothly the main truck (Fig.2) [5, 15].

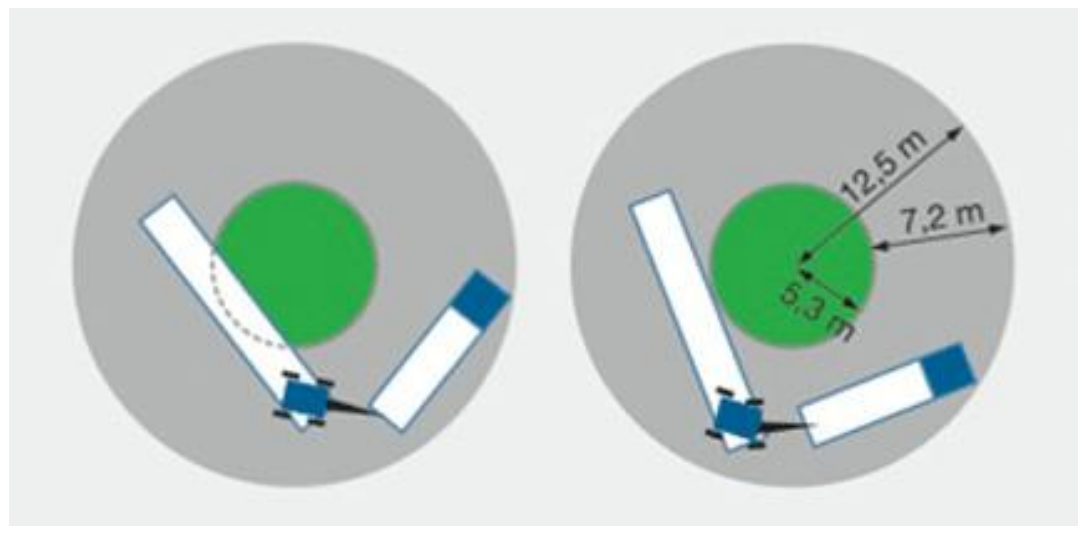

Fig.2 Distance the EMS equipped with a dolly truck covers while driving through a roundabout [15] 
Implementation of modular trucks into road transport

Koncepcja wdrożenia zespołów modułowych $w$ transporcie drogowym

For the purpose of driving through roundabouts situated within the national roads whose inner isle radius is $5 \mathrm{~m}$, the EMS should be technically adjusted by being equipped with:

- a dolly truck with an active turning system,

- semi-trailer with one articulation point with a turning axle,

- if there are none of the above mentioned elements there should be two points of articulation.

The EMS moving on the remaining roads, that is, motorways and expressways will not have any problems with going through these objects because their central islands have long diameters and long exit radiuses [6].

\section{Safety of road traffic}

Analyzing data from the vehicles used in Holland it was found that in the years 2007-2010 there were 19 accidents with involvement of the EMS. This is a very small percent of all the accidents that were reported on the road in that period. In regard to the number of casualties there was only one road event like that. In the remaining collisions only material losses were reported. There were no accidents with participation of pedestrians or cyclists. Accident rate with participation of the EMS is very small whereas the average distance they cover is longer as compared to standard trucks [11].

After having analyzed the causes of all accidents with participation of the EMS it can be said that the collisions were caused by passenger car drivers. At the same time the legal regulations on the use of the EMS should provide safety of transport services performance. A vehicle of this type should have the following equipment:

- technologically braking systems,

- axle load measurement system,

- set of mirrors consistent with the newest European rules,

- side protection between the wheels,

- side light marking,

- rear information sign about the combination contour and length.

Additionally, having performed an analysis of the time necessary to overtake the EMS it was found that while overtaking a standard truck going at the speed of 80 $\mathrm{km} / \mathrm{h}$, a passenger vehicle moving at $100 \mathrm{~km} / \mathrm{h}$ travels a distance of $565 \mathrm{~km}$ from the beginning to the end of the maneuver. In turn, while overtaking the EMS a vehicle going at the speed of $80 \mathrm{~km} / \mathrm{h}$ it covers a distance of $597 \mathrm{~m}$. Thus, comparing these two cases it can be observed that the difference is not significant.

\section{Energy efficiency of modular systems}

On the basis of operational data obtained from Holland it was found that in effect of implementation of truck trains is this country $\mathrm{CO}_{2}$ and $\mathrm{NOx}$ have been reduced:

- from 63 to $56 \mathrm{~g}$ per ton-kilometer $\mathrm{CO}_{2}$ - it accounts for $11 \%$ of $\mathrm{CO}_{2}$ reduction,

- from 0.4 to $0.37 \mathrm{~g}$ per ton of NOx - which accounts for $14 \%$ of NOx reduction. 
A test performed with the use of 11000 EMS vehicles revealed that reduction of exhaust fumes for $\mathrm{NOx}$ is $4 \%$ and $6 \%$ for $\mathrm{CO}_{2}$. It was estimated that the European Modular System can travel $41 \%$ more ton-kilometers per one liter.

Also in Germany, introduction of the EMS has had a positive influence on the environment. Reduction of $\mathrm{CO}_{2}$ and $\mathrm{NOx}$ was $33 \%$ [11].

Using this data the authors of this study performed estimation of energy efficiency for some routes in Poland. It was assumed that the EMS would be moving along A1, A2, A4 and S4 roads for which the following data was established:

- average 24 hours average traffic on these routes is 18763 vehicles per 24 hours whereas a yearly traffic -54566 ,

- the share of trucks is $15 \%$,

- the share of truck tractors is $8 \%$,

- the average transport distance accounts for $230 \mathrm{~km}$ of the road transport distance [10].

Thus, it was found that for almost all analyzed cases, $\mathrm{CO}_{2}$ emitted by the EMS was lower [10] than for standard trucks. Only EMS 40t, is an exception whose fuel consumption rises for transport of heavier loads.

\section{Advisability of road modular systems implementation on the example of a selected transport company}

An analysis of advisability of implementation of the EMS into the national road transport was performed on the basis of a selected transport company providing transport services in a 'linear' system between selected logistic centers $[2,6]$.

The analyzed company is located in the Wielkopolskie Province. It provides services connected with transport of shipments to 17 departments all over Poland. Currently delivery of shipments is performed by means of a truck tractor with a side open semi-trailer type which can accommodate 33 Euro pallets. The rate accepted for each transport is 2.90 PLN for one vehicle kilometers traveled. Now the cargo is delivered to 5 out of 17 divisions in the amount exceeding 33 euro pallets which causes increased demand for vehicles. The proposed changes are supposed replace vehicles which provide transport services along these five routes with EMS vehicles. Analyzing legal restrictions and all aspects connected with the infrastructure it is proposed to introduce EMS trucks in D configuration (Fig. 1), consisting of a truck with load capacity for 19 palettes and a semi-conductor for 33 palettes. These vehicles will move over the following roads:

- Leszno: DK36, E261,

- Łódź: DK36, DK25, DK12, E67, DK14,

- Gdańsk: DK36, E261, E75, E77, DK89,

- Czestochowa: DK36, E261, E67, DK74, DK45, DK43,

- Kraków: DK36, E261, E67, E40, E77.

The rate equal to 3.80pln was estimated for one vehicle kilometer traveled. In order to determine costs of transport for currently used trucks and for the proposed oversize vehicles, the number of kilometers between particular divisions was taken into consideration. The costs of transport for both types of vehicles are presented in table 3 . 
Implementation of modular trucks into road transport

Koncepcja wdrożenia zespołów modulowych $w$ transporcie drogowym

Tab. 3 Cost of transport performed by standard vehicles and by the EMS.

\begin{tabular}{|l|c|c|}
\hline Division & $\begin{array}{c}\text { Transport cost } \\
\text { (standard) }\end{array}$ & $\begin{array}{c}\text { Transport cost } \\
\text { (EMS) }\end{array}$ \\
\hline Leszno & $230.54 \mathrm{pln}$ & $149.47 \mathrm{pln}$ \\
\hline Łódź & $1239.80 \mathrm{pln}$ & $834.80 \mathrm{pln}$ \\
\hline Gdańsk & $2317.40 \mathrm{pln}$ & $1841.47 \mathrm{pln}$ \\
\hline Częstochowa & $1332.68 \mathrm{pln}$ & $988.18 \mathrm{pln}$ \\
\hline Kraków & $2190.62 \mathrm{pln}$ & $1400.41 \mathrm{pln}$ \\
\hline
\end{tabular}

The mean value of a palette/kilometer was calculated for particular divisions (table 4). Calculations were performed using dependence:

$$
\mathrm{Kp} / \mathrm{Lk} / \mathrm{Lp}=\mathrm{Pk}
$$

where:

$\mathrm{Kp}$ - transport cost of a given number of palettes,

$\mathrm{Lk}$ - number of kilometers between departments,

$\mathrm{Lp}$ - number of transported palettes,

$\mathrm{Pk}$ - value of palette/kilometer.

Tab. 4 Mean values of palette/kilometer for particular routes.

\begin{tabular}{|l|c|c|}
\hline Division & Standar trucks & EMS \\
\hline Leszno & $0.124 \mathrm{pln}$ & $0.080 \mathrm{pln}$ \\
\hline Łódź & $0.137 \mathrm{pln}$ & $0.089 \mathrm{pln}$ \\
\hline Gdańsk & $0.119 \mathrm{pln}$ & $0.083 \mathrm{pln}$ \\
\hline Częstochowa & $0.114 \mathrm{pln}$ & $0.075 \mathrm{pln}$ \\
\hline Kraków & $0.144 \mathrm{pln}$ & $0.092 \mathrm{pln}$ \\
\hline
\end{tabular}

Transport cost of one palette transport between the divisions are presented in table 5 .

Tab. 5 Cost of transport of one palette.

\begin{tabular}{|l|c|c|}
\hline Division & Standard trucks & EMS \\
\hline Leszno & $4.70 \mathrm{pln}$ & $3.05 \mathrm{pln}$ \\
\hline Łódź & $28.18 \mathrm{pln}$ & $18.97 \mathrm{pln}$ \\
\hline Gdańsk & $45.44 \mathrm{pln}$ & $36.11 \mathrm{pln}$ \\
\hline Częstochowa & $25.63 \mathrm{pln}$ & $19.00 \mathrm{pln}$ \\
\hline Kraków & $48.68 \mathrm{pln}$ & $31.12 \mathrm{pln}$ \\
\hline
\end{tabular}

The analyze company transports shipments systematically for 5 davs a week. Transport costs for a week, quarter, and month are presented in tables 6 and 7 and the results are presented in the graphic form in figure 3.

Tab. 6 Costs of transport by a standard system in different time periods.

\begin{tabular}{|l|c|c|c|}
\hline Department & Week & Month & Quarter \\
\hline Leszno & $1152.70 \mathrm{pln}$ & $4610.80 \mathrm{pln}$ & $13832.40 \mathrm{pln}$ \\
\hline Łódź & $6199 \mathrm{pln}$ & $24796 \mathrm{pln}$ & $73488 \mathrm{pln}$ \\
\hline Gdańsk & $11587 \mathrm{pln}$ & $46348 \mathrm{pln}$ & $139044 \mathrm{pln}$ \\
\hline Częstochowa & $6663.40 \mathrm{pln}$ & $26653.60 \mathrm{pln}$ & $79960.80 \mathrm{pln}$ \\
\hline Kraków & $10953.10 \mathrm{pln}$ & $43812.40 \mathrm{pln}$ & $131437.20 \mathrm{pln}$ \\
\hline Total & $36555.20 \mathrm{pln}$ & $146220.80 \mathrm{pln}$ & $438662.40 \mathrm{pln}$ \\
\hline
\end{tabular}


Tab. 7 Transport costs by EMS in different time periods.

\begin{tabular}{|l|c|c|c|}
\hline Division & Week & Month & Quarter \\
\hline Leszno & $747.35 \mathrm{pln}$ & $2989.40 \mathrm{pln}$ & $8968.20 \mathrm{pln}$ \\
\hline Łódź & $4174 \mathrm{pln}$ & $16696 \mathrm{pln}$ & $50088 \mathrm{pln}$ \\
\hline Gdańsk & $9207.35 \mathrm{pln}$ & $36829.40 \mathrm{pln}$ & $110488.20 \mathrm{pln}$ \\
\hline Częstochowa & $4940.90 \mathrm{pln}$ & $19763.60 \mathrm{pln}$ & $59290.80 \mathrm{pln}$ \\
\hline Kraków & $7002.05 \mathrm{pln}$ & $28008.20 \mathrm{pln}$ & $84024.60 \mathrm{pln}$ \\
\hline Total & $26071.65 \mathrm{pln}$ & $104286.60 \mathrm{pln}$ & $312859.80 \mathrm{pln}$ \\
\hline Savings & $10483.55 \mathrm{pln}$ & $41934.20 \mathrm{pln}$ & $125802.60 \mathrm{pln}$ \\
\hline
\end{tabular}

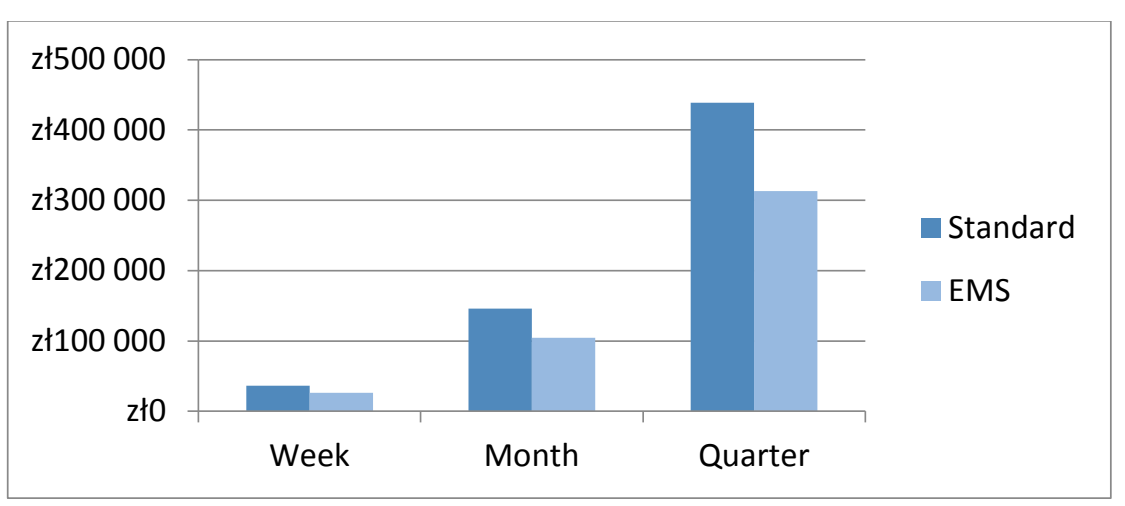

Fig. 3 Diagram of transport costs generated by the EMS and standard trucks in different time periods

Analyzing the above results it can be noticed that implementation of modular systems into the considered company brings savings in the amounts:

- 10483.55 PLN for weekly transport of shipments during one week,

- 41934.20 PLN for transport of shipments during one month,

- 125802.60 PLN for transport of shipments during one month.

The proposed changes reduce transport costs by $28.7 \%$.

\section{Conclusions}

Constantly increasing demand for road transport services inseparably connected with the society economic growth has an adverse effect on the environment including: noise production, exhaust fumes emission, street congestion and road accidents. Occurrence of these negative phenomena need to be minimized. The concept of modular truck transport is a solution which allows to prevent or reduce these phenomena. Using a smaller number of vehicles to provide transport services reduces the possibility of accident related threats, road congestion, fuel consumption as well as emission of exhaust gases into the atmosphere.

The analysis of the Polish road infrastructure carried out in this study has revealed that the modular systems could by authorized to run on the motorways, expressways and some selected main roads.

It is recommended to change requirements concerning design and construction of the road infrastructure to adjust it to increased dimensions of the vehicles. 
Implementation of modular trucks into road transport

Koncepcja wdrożenia zespołów modułowych $w$ transporcie drogowym

On the example of the company analyzed in this study it can undoubtedly be stated that replacing standard trucks with modular trucks of EMS type brings measurable profits such as: reduction of the number of vehicles in service thereby relieving the traffic and decreasing the number of drivers, without deteriorating the road safety, and reduction of the negative impact on the environment.

\section{References}

[1] Akerman I., Jonsson R., European Modular System for road freight transport experiences and possibilities, Rapport 2007:2E, Sztokholm 2007.

[2] Błajda Ł., Analiza i ocena celowości wdrożenia drogowych zespołów modułowych w Polsce.

[3] Lińćák Ń., Olejnik K., Woźniak G., Propozycje i ocena możliwości zwiększenia rzeczywistej pracy przewozowej środków transportu drogowego, Motor Transport Institute, Warszawa 2012.

[4] Lumsden K., Truck Masses and Dimensions - Impact on Transport Efficiency, Department of Logistics and Transportation, Chalmers University of Tehchnology, Gothenburg 2004.

[5] Milewski D., Wiśnicki B., Wpływ kosztów eksploatacji wielkogabarytowych zestawów drogowych na rynek transportowy w Polsce, Zeszyty Naukowe Uniwersytetu Szczecińskiego. Problemy Transportu i Logistyki, 26/2014.

[6] Muślewski Ł., Lewalski M., Woropay M., Analysis and evaluation of application of car modular systems in polish road transport, Journal of Kones, 22(4)/2015.

[7] Poliński J., Konkurencja pociaggów drogowych dla transportu kolejowego w Europie, Przegląd Komunikacyjny, 5/2014.

[8] Raczyński J: Wizja megaciężarówek - kolejowe przewozy towarowe wobec kolejnych zagrożeń, Rynek Kolejowy, 10/2007.

[9] Wiśnicki B., Galor W., Uwarunkowania przewozu ładunków pojazdami niestandardowymi w Europie, Logistyka, 2/2010.

[10] Załoga E., Milewski D., Kwarciński T., Wpływ planowanej przez Komisję Europejska zmiany dyrektywy rady 96/53/we z dnia 25 lipca $1996 \mathrm{r}$. ustanawiająca dla niektórych pojazdów drogowych poruszających się na terytorium wspólnoty maksymalne dopuszczalne wymiary w ruchu krajowym i międzynarodowym oraz maksymalne dopuszczalne obciążenia w ruchu międzynarodowym na sektor transportu w Polsce. Ekspertyza, Szczecin 2012.

[11] Longer and Heavier Vehicles in the Netherlands. Facts, figures and experiences in the period 1995-2010, Ministry of Transport, 2010.

[12] Rozporządzenie Ministra Transportu i Gospodarki Morskiej z dnia 2 marca 1999 r. w sprawie warunków technicznych, jakim powinny odpowiadać drogi publiczne i ich usytuowanie, (Dziennik Ustaw. z 1999 r., Nr 43, poz. 430).

[13] http://www.whitlockbullbars.com.au

[14] http://www.smh.com.au

[15] http://www.krone-trailer.com

[16] http://www.wikiwand.com

[17] http://upload.wikimedia.org

[18] http://www.verkehrsrundschau.de 
[19] http://h-a.d-cd.net

[20] http://www.marcotran.com

[21] http://www3.picturepush.com

[22] http://www.nhvr.gov.au

[23] http://www.smart-trucking.com

[24] http://www.truckandtrailer.ca

[25] http://www.mexicotrucker.com

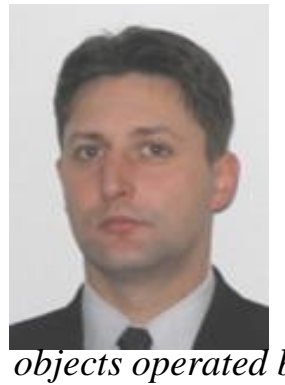

Lukasz Muślewski Ph.D. Eng., associate professor, Manager of the Department of Maintenance and Transport Operation at the Faculty of Mechanical Engineering of $J \& J$ Sniadeccy University of Science and Technology in Bydgoszcz. In his academic research he deals with the problems associated with operation quality of complex technical systems particularly transport systems. His research covers issues connected with reliability, safety, efficiency and environment friendliness of sociotechnical systems whose operation is affected by operators, technical objects operated by them and other environmental factors (Share 50\%).

Bogdan Landowski, Ph.D works in the Department of Transport

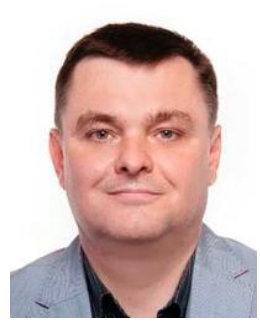
and Machine Maintenance of the Faculty of Mechanical Engineering in the University of Science and Technology in Bydgoszcz. His scientific work deals with the problems of complex maintenance systems effectiveness, as well as of modelling of maintenance processes and systems. The research area covers application of Markov decision process theory for mathematical modelling of maintenance processes. His scientific investigations are focused on numerical modelling of maintenance processes and systems (Share 30\%).

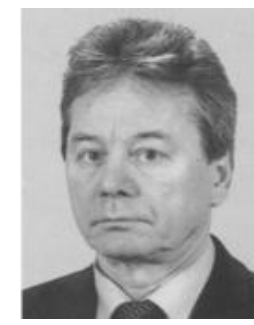

Professor Maciej Woropay, Ph.D. Eng. His academic studies include the problems of system theory, reliability and safety theory as well as of operation processes control in complex biotechnical systems, in particular control of these processes in municipal transport systems. He is the author and co-author of over160 scientific papers publish in Poland and internationally as well as academic textbooks and lecture collections, the supervisor of more than 180 master's and engineer's theses as well as doctoral dissertations (Share 10\%).

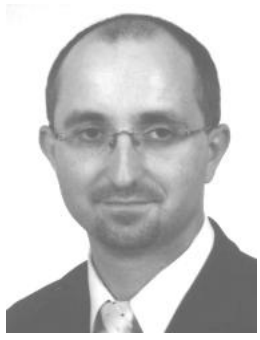

Assoc. Prof. Klaudiusz Migawa, Ph.D. Eng., member of the Faculty of Mechanical Engineering of the UTP University of Science and Technology in Bydgoszcz. In his academic studies, he is preoccupied with the problems of evaluation and control of the level of efficiency, reliability, availability as well as safety of the complex systems of technical objects operation. He is the author of scientific papers in the field of modeling of systems and operation processes of means of transport with the implementation of stochastic processes (Share 10\%). 
Implementation of modular trucks into road transport

Koncepcja wdrożenia zespołów modułowych $w$ transporcie drogowym

\section{KONCEPCJA WDROŻENIA ZESPOLÓW MODULOWYCH W TRANSPORCIE DROGOWYM}

\section{Wstęp}

Ładowność (masowa) pojazdów jest podstawową cechą przy wykonywaniu przewozu ładunków o stosunkowo wysokiej gęstości. Ograniczenie jej wynika przede wszystkim z ograniczenia administracyjnego dotyczącego dopuszczalnej całkowitej masy zespołu pojazdów. Podstawowym aktem prawnym, który reguluje dopuszczalne parametry pojazdów na drogach Unii Europejskiej jest dyrektywa 96/53. Ogranicza ona masę całkowitą pojazdów do 40t oraz długość zestawu drogowego do $18.5 \mathrm{~m}$. Natomiast należy podkreślić, że każdy kraj ma możliwość wprowadzenia odstępstw od tej dyrektywy. Dopuszczenie do ruchu drogowego dłuższych i cięższych pojazdów jedynie na swoim terytorium możliwe jest w ramach powołania się na tzw. koncepcję modułową oraz brak naruszania konkurencji w sektorze transportowym. Liczba państw, które zdecydowały się wprowadzić tego rodzaju odstępstwa jest coraz liczniejsza a liderami wdrożeń takich rozwiązań są kraje skandynawskie. Mając na uwadze ogół korzyści i zagrożeń wynikających $\mathrm{z}$ tego rodzaju rozwiązań, w niniejszej pracy dokonano analizę możliwości i celowości wdrożenia drogowych zespołów modułowych w krajowym transporcie drogowym w Polsce.

\section{Analiza istniejących rodzajów drogowych systemów modułowych na świecie}

Przewóz ładunków dłuższymi i cięższymi pojazdami od standardowych powiązany jest $\mathrm{z}$ problematyką międzygałęziowej konkurencji w transporcie. Porównując Europejski rynek przewozów drogowych z rynkiem Ameryki Północnej, Australii czy Azji Północnej łatwo dostrzec jego specyfikę [22-25]. Europa to znacznie bardziej zaludniony kontynent, $\mathrm{z}$ gęstą infrastrukturą drogową cechującą się wieloma ograniczeniami z zakresu parametrów technicznych drogi [7]. Natomiast cel, jakim jest powiększenie ładowności oraz pojemności pojazdów ciężarowych, jest kluczowy pod względem skutecznego konkurowania drogowych przewoźników z transportem kolejowym oraz rzeczno-morskim. Każdy metr sześcienny lub tona więcej na naczepie to zmniejszone koszty jednostkowe transportu, a koszty te zawsze przemawiały na korzyść statków i kolei. W ciągu ostatniego półwiecza dopuszczalna maksymalna masa pojazdów w państwach europejskich zwiększyła się od 10 do 30 ton, czyli nawet o 50\% [4]. Jest to możliwe między innymi dzięki takim rozwiązaniom jak tzw. „koncepcja modułowa", w której dopuszczony do ruchu pojazd nienormatywny lub zespół pojazdów może być zamieniony przez nienormatywny pociąg drogowy zbudowany $\mathrm{z}$ pojazdów, naczep albo przyczep zgodnych $\mathrm{z}$ wymienionymi we wstępie parametrami. 
Innymi słowy, państwo unijne dopuszczające do ruchu dłuższe pojazdy niż te wskazane w Dyrektywie, jest zmuszone zezwolić również na przemieszczanie się dłuższych pociągów drogowych zbudowanych $\mathrm{z}$ normatywnych modułów (pojazdów, przyczep lub naczep). Wiele państw wykorzystało możliwości tych odstępstw, o czym świadczą dane zamieszczone w tabeli 1 [7].

Tab.1 Maksymalne dopuszczalne masy oraz wymiary pojazdów $w$ wybranych państwach UE [7].

\begin{tabular}{|c|c|c|c|c|c|}
\hline Kraj & $\begin{array}{c}\text { Masa } \\
\text { pojazdu } \\
\text { brutto [t] }\end{array}$ & $\begin{array}{c}\text { Wysokość } \\
{[\mathrm{m}]}\end{array}$ & $\begin{array}{c}\text { Szerokość } \\
{[\mathrm{m}]}\end{array}$ & $\begin{array}{c}\text { Pojazd } \\
\text { przegubowy }\end{array}$ & $\begin{array}{c}\text { Pociąg } \\
\text { drogowy }\end{array}$ \\
\hline $\begin{array}{c}\text { Dyrektywa } \\
\text { 96/53/WE }\end{array}$ & 40,00 & 4,00 & 2,55 & 16,50 & 18,75 \\
\hline Belgia & 44,00 & 4,00 & 2,55 & 16,50 & 18,75 \\
\hline Czechy & 48,00 & 4,00 & 2,50 & 16,50 & 18,00 \\
\hline Dania & 48,00 & 4,00 & 2,55 & 16,50 & 18,75 \\
\hline Finlandia & 60,00 & 4,20 & 2,60 & 16,50 & 25,25 \\
\hline Francja & 40,00 & Nie 0 Kreślono & 2,55 & 16,50 & 18,75 \\
\hline Holandia & 50,00 & 4,00 & 2,55 & 16,50 & 18,75 \\
\hline Irlandia & 44,00 & 4,00 & 2,55 & 16,50 & 18,75 \\
\hline Luksemburg & 44,00 & 4,00 & 2,55 & 16,50 & 18,75 \\
\hline Niemcy & 40,00 & 4,00 & 2,60 & 16,50 & 18,75 \\
\hline Polska & 40,00 & 4,00 & 2,60 & 16,50 & 18,75 \\
\hline Szwecja & 60,00 & Nie $0 k$ kreślono & 2,55 & 25,25 & 24,00 \\
\hline W. Brytania & 44,00 & Nie 0 kreślono & 2,55 & 16,50 & 18,75 \\
\hline Włochy & 44,00 & 4,00 & 2,55 & 16,50 & 18,75 \\
\hline
\end{tabular}

W różnych krajach oraz forach dyskusyjnych pojazdy takie nazywa się: Gigaliners, Megatrucks, Jumbotrucks, Monstertrucks, Longer and Heavier Vehicles (LHV), EuroCombi, Öko-Kombis, European Modular System (EMS) [3,7-9,17-21]. Niniejsze pociągi drogowe tworzone są ze standardowych pojazdów drogowych, takich jak:

- ciągniki siodłowe (moduł A),

- dwu albo trzyosiowe naczepy o długości 13,6 m (moduł B),

- dwu albo trzyosiowych przyczep o długościach 7,82 m z centralnym położeniem osi (moduł C),

- trzyosiowe naczepy o specjalnej konstrukcji z siodłem (moduł D),

- trzy lub czteroosiowy samochód ciężarowy (moduł E),

- trzyosiowe przyczepy (moduł F),

- dwuosiowy wózek z siodłem tzw. ,dolly” (moduł G) [1].

Wyszczególnione powyżej moduły, stanowią elementy składowe pojazdów o różnych konfiguracjach. 
Implementation of modular trucks into road transport

Koncepcja wdrożenia zespołów modułowych $w$ transporcie drogowym

Wyróżnić można pięć następujących konfiguracji w budowie pociągów drogowych (rysunek 1) [7]:

a) $\mathrm{A}+\mathrm{B}+\mathrm{C}$ (Rys.2.5),

b) $\mathrm{A}+\mathrm{D}+\mathrm{B}$ (Rys.2.6),

c) $\mathrm{E}+\mathrm{F}$ (Rys.2.7),

d) $\mathrm{E}+\mathrm{G}+\mathrm{B}$ (Rys.2.8),

e) $\mathrm{E}+\mathrm{C}+\mathrm{C}$ (Rys.2.9)

$\mathrm{W}$ interpretacji graficznej przedstawia się to następująco:

a)

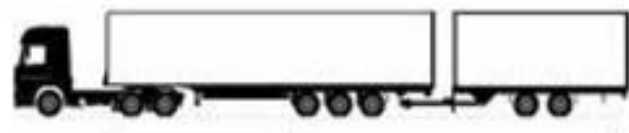

b)

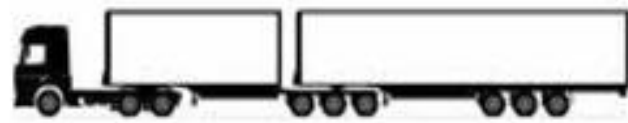

c)

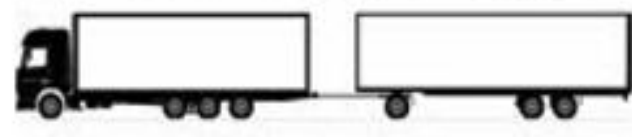

d)

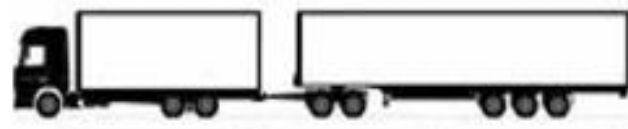

e)

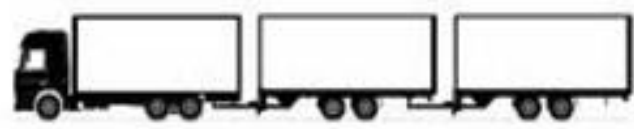

Rys.1 Rozwiązania najczęściej spotykanych pociagów drogowych w Europie [7]

Analizując natomiast rynek modułowych zestawów drogowych na świecie należy podkreślić, że największe $\mathrm{z}$ nich eksploatowane są $\mathrm{w}$ Australii (największe i najcięższe dopuszczone do ruchu pojazdy, których masa dochodzi do 200t.), Kanadzie, USA i Meksyku. Pociągi drogowe są wykorzystywane do przewożenia wszystkich rodzajów towarów, w tym żywego inwentarza, paliwa, rud minerałów i towaru drobnicowego a ich opłacalność przyczyniła się w znacznym stopniu do rozwoju gospodarczego najbardziej odległych obszarów.

\section{Infrastrukturalne aspekty wdrożenia drogowych zespołów modułowych w Polsce}

Podział dróg publicznych ze względu na kategorie wynika z funkcji, jaką spełnia droga w polskiej sieci drogowej. Wyróżnia się następujące kategorie dróg:

- drogi krajowe (należą do klasy A, S, GP, wyjątkowo G),

- drogi wojewódzkie (należą do klasy G, Z, wyjątkowo GP),

- drogi powiatowe (należą do klasy G, Z, wyjątkowo L),

- drogi gminne (należą do klasy L, D, wyjątkowo Z) [12]. 
Łukasz Muślewski, Bogdan Landowski, Maciej Woropay, Klaudiusz Migawa

Dopuszczalne, maksymalne naciski pojedynczej osi pojazdu na nawierzchnię drogi określonej klasy zamieszczono w tabeli 2.

Tab. 2 Dopuszczalny maksymalny nacisk na oś pojazdu [12].

\begin{tabular}{|l|c|}
\hline Klasa drogi & $\begin{array}{c}\text { Dopuszczalny nacisk } \\
\text { na oś pojazdu (t) }\end{array}$ \\
\hline A, S & 11.5 \\
\hline GP & $11.5,10^{*}$ \\
\hline G, Z, L, D & $10,8^{*}$ \\
\hline
\end{tabular}

Dopuszcza się podczas przebudowy lub remontu drogi.

Niektóre drogi krajowe w zależności od poszczególnych odcinków mogą posiadać różne dopuszczalne naciski na oś. W Polsce taką drogą jest np. DK5. Ze względu na wymiary i masę całkowitą, EMS poruszałyby się tylko po głównej sieci dróg kołowych tj. po autostradach, drogach ekspresowych i drogach krajowych. W związku ze zwiększoną liczbą osi w EMS, obciążenie poszczególnych z nich jest podobne jak w standardowych pojazdach ciężarowych. Drogowy zespół modułowy o całkowitej masie do 60t, posiadający 7 osi wywiera około $8.57 \mathrm{t}$ na jedną oś. Zestawiając tą wartość $\mathrm{z}$ naciskiem wywieranym na oś przez zestawy standardowe różnica jest nieduża. W zestawie o DMC 40t z pięcioma osiami, średni nacisk na pojedynczą oś wynosi 8t. Dlatego z punktu widzenia obciążenia osi, EMS mogłyby być dopuszczone do ruchu na drogach głównych.

Kolejnym elementem infrastruktury drogowej w Polsce, który teoretycznie mógłby być przeszkodą dla wprowadzenia EMS są mosty oraz wiadukty. Zwiększenie DMC pojazdów ciężarowych nie wpłynęłoby negatywnie na infrastrukturę tychże obiektów, ponieważ w tym przypadku również głównym wskaźnikiem jest obciążenie osi. Jeśli ciężar byłby odpowiednio rozłożony na poszczególne z nich, taki zestaw nie stanowiłby zagrożenia dla powyższych konstrukcji. Warto zauważyć, że po tego typu obiektach nierzadko poruszają się środki transportu ponadnormatywnego, których masa całkowita znacznie przekracza $40 \mathrm{t}$, a mimo to nie ingerują one $\mathrm{w}$ ich stan [6].

Największym problemem polskiej infrastruktury drogowej $\mathrm{w}$ przypadku wprowadzenia do ruchu EMS są skrzyżowania i ronda. W obecnej chwili standardowe zestawy o długościach $16.5 \mathrm{~m}$ i $18.75 \mathrm{~m}$ mają problemy z przejazdem przez skrzyżowania, gdyż promień łuku dla skanalizowanych wlotów dróg klasy G, GP, Z i D wynosi 10m, a dla nieskanalizowanych wlotów dróg klasy G oraz $\mathrm{Z} 8 \mathrm{~m}$ [12].

Natomiast stosując się do przepisów dotyczących przejazdu przez skrzyżowania nieskanalizowane, pojazdy ciężarowe o długościach $16.5 \mathrm{~m}, 18.75 \mathrm{~m}$ oraz $25.25 \mathrm{~m}$ wyposażone w osie skrętne o minimalnym promieniu skrętu $12.5 \mathrm{~m}$ i $14.5 \mathrm{~m}$ mogą pokonać każde skrzyżowanie posiadające wyspy najazdowe. Jedynym utrudnieniem dla pojazdów o długości $25.25 \mathrm{~m}$ są skrzyżowania skanalizowane nieposiadające wysp najazdowych. Na drogach krajowych skrzyżowania tego typu występują rzadko jednak zalecane jest ich przebudowanie. 
Implementation of modular trucks into road transport

Koncepcja wdrożenia zespołów modułowych $w$ transporcie drogowym

Dobrą alternatywą dla zestawów posiadających osie skrętne jest wózek dolly, którego układ skrętny jest aktywny. Dzięki temu EMS bezproblemowo pokonuje drogę skrętu gdyż układ taki powoduje, że zespół wybiega na wewnętrznym promieniu o ok. $5.3 \mathrm{~m}$ natomiast naczepa $\mathrm{w}$ sposób płynny podąża za śladami samochodu ciężarowego (Rys.2) [5,15].

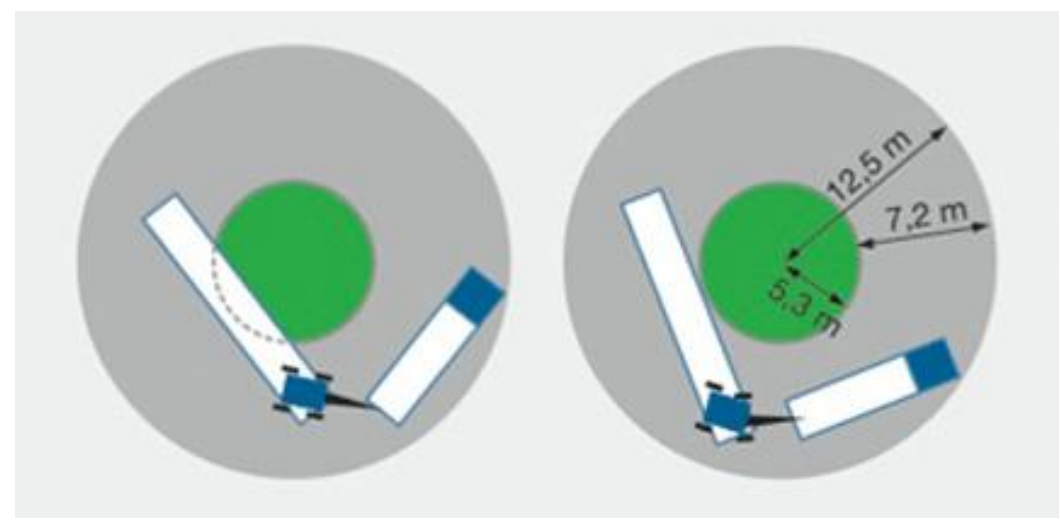

Rys.2 Droga EMS wyposażonego w wózek dolly po rondzie [15]

$\mathrm{Z}$ punktu widzenia przejazdu przez ronda na drogach krajowych, gdzie promień wewnętrznej wyspy wynosi 5m, pojazdy EMS powinny być w odpowiedni sposób dostosowane technicznie:

- zespół wyposażony w wózek dolly z aktywnym układem skrętnym,

- naczepa zespołu z jednym punktem przełamania posiadająca oś skrętną,

- w przypadku braku powyższych elementów, zespół powinien posiadać dwa punkty przełamania.

EMS przemieszczające się po pozostałych drogach tj. autostradach oraz drogach ekspresowych nie będą miały problemu z pokonywaniem tych obiektów przez wzgląd na dużą średnicę wysp wewnętrznych i na duże promienie zjazdów [6].

\section{Bezpieczeństwo w ruchu drogowym}

Analizując dane na przykładzie pojazdów eksploatowanych w Holandii stwierdzono, że w latach 2007-2010 odnotowano 19 wypadków z udziałem EMS. Stanowi to znikomy procent wszystkich wypadków na drogach w tym okresie. Koncentrując się wyłącznie na liczbie ofiar oraz osobach rannych odnotowano tylko jeden taki przypadek. W pozostałych zdarzeniach poniesiono wyłącznie straty materialne. Wypadków z udziałem pieszych i rowerzystów nie odnotowano. Procent wypadkowości z udziałem zestawów EMS jest znikomy, natomiast średnia długość pokonywanych przez nie tras jest większa, niż przez standardowe pojazdy ciężarowe [11].

Natomiast po dokonaniu analizy przyczyn wszystkich wypadków drogowych z udziałem EMS można stwierdzić, iż głównymi sprawcami wypadków byli kierowcy pojazdów osobowych. 
Jednocześnie wprowadzone przepisy dotyczące poruszania się EMS mają zagwarantować bezpieczeństwo podczas realizacji zadań transportowych. Pojazd tego typu posiadać powinien następujące wyposażenie:

- zaawansowane układy hamulcowe,

- system pomiaru obciążenia osi,

- zestaw lusterek zgodny z najnowszymi europejskimi przepisami,

- zabezpieczenie boczne pomiędzy kołami,

- boczne oznakowania świetlne,

- tylny znak informujący o konturze kombinacji oraz długości.

Dodatkowo analizując problematyczną kwestię czasu wyprzedzania zestawów EMS stwierdzono, że w przypadku standardowego zestawu jadącego z prędkością $80 \mathrm{~km} / \mathrm{h}$, pojazd osobowy poruszający się z prędkością $100 \mathrm{~km} / \mathrm{h}$ od chwili rozpoczęcia jego wyprzedzania aż do zakończenia manewru pokonuje odległość $565 \mathrm{~m}$. Z kolei wyprzedzając EMS jadący $80 \mathrm{~km} / \mathrm{h}$ pokonuje odległość $597 \mathrm{~m}$. Porównując zatem te dwa przypadki widać, że różnica jest niewielka.

\section{Efektywność energetyczna zespołów modułowych}

$\mathrm{Na}$ przykładzie danych eksploatacyjnych pozyskanych na terenie Holandii stwierdzono, że wprowadzenie pojazdów EMS wpłynęło na zmniejszenie emisji $\mathrm{CO}_{2}$ i NO x w liczbie:

- z 63 do $56 \mathrm{~g}$ na tonokilometr $\mathrm{CO}_{2}-$ stanowi to $11 \%$ redukcji $\mathrm{CO}_{2}$,

- z 0.4 do $0.37 \mathrm{~g}$ na tonę $\mathrm{NO}_{\mathrm{x}}$ - co stanowi $14 \%$ redukcji $\mathrm{NO}_{\mathrm{x}}$.

Test przeprowadzony przy udziale 11000 pojazdów EMS wykazał, iż redukcja emisji spalin dla $\mathrm{NO}_{x}$ wynosi $4 \%$ oraz $6 \%$ dla $\mathrm{CO}_{2}$. Oszacowano, że Europejski System Modułowy może wykonać o $41 \%$ więcej tonokilometrów na jeden litr paliwa.

Również w Niemczech wprowadzenie EMS wpłynęło korzystnie na środowisko. Redukcja $\mathrm{CO}_{2}$ i $\mathrm{NO}_{\mathrm{x}}$ wyniosła tam $33 \%$ [11].

Korzystając $\mathrm{z}$ tych danych autorzy ekspertyzy wykonali szacunkowe obliczenia efektywności energetycznej dla niektórych tras w Polsce. Przyjęto, że EMS będą się poruszać po trasach A1, A2, A4 i S4 dla których ustalono następujące dane:

- średni dobowy ruch pojazdów na trasach tych wynosi 18763 pojazdów na dobę, natomiast roczny ruch -54566 ,

- udział pojazdów ciężarowych wynosi $15 \%$,

- udział ciągników siodłowych w ogólnej ilości pojazdów wynosi 8\%,

- średnia odległość przewozu w drogowym transporcie wynosi $230 \mathrm{~km} \mathrm{[10].}$

Analizując wyniki badań dotyczące emisja $\mathrm{CO}_{2}$ [10] stwierdzono, że w prawie wszystkich przypadkach emisja $\mathrm{CO}_{2}$ jest przez pojazd EMS jest mniejsza niż przy standardowych pojazdach ciężarowych. Wyjątkiem jest tylko EMS 40 t, w przypadku którego zużycie paliwa zwiększa się przy transporcie cięższych ładunków. 
Implementation of modular trucks into road transport

Koncepcja wdrożenia zespołów modułowych w transporcie drogowym

\section{Analiza celowości wdrożenia drogowych zespołów modułowych na przykładzie wybranej firmy transportowej}

Analize celowości wdrożenia zestawów EMS w krajowym transporcie drogowym, dokonano na przykładzie wybranego przedsiebiorstwa transportowego, realizuiacego przewozy w systemie „liniowym”, pomiędzy wyróżnionymi centrami logistycznymi $[2,6]$.

Omawiana firma znaiduie sie w województwie wielkopolskim. Przedsiebiorstwo zaimuie sie rozwożeniem przesyłek do 17 oddziałów na terenie całei Polski. Na chwile obecna dostarczanie przesyłek do poszczególnych oddziałów realizowane jest przy pomocy ciagnika siodłowego z naczepa typu „burta” mogaca pomieścić 33 palety Euro. Przyieta stawka podczas każdego przewozu wynosi 2,90 zł za jeden wozokilometr. Obecnie do 5 spośród 17 oddziałów dostarczany iest towar W ilości przekraczaiacei 33 europalety co powoduie zwiekszone zapotrzebowanie na liczbe poiazdów. Sugerowane zmiany maja na celu zastapienie na tych pieciu trasach obecnie wykorzystywanych standardowych poiazdów ciężarowych poiazdami EMS. Analizuiac uwarunkowania prawne oraz ogół aspektów infrastrukturalnych, proponuie sie wprowadzenie do eksploatacii zestawów EMS $\mathrm{w}$ konfiguracii D (Rys. 1), złożonego $\mathrm{z}$ poiazdu ciężarowego mieszczacego 19 palet oraz naczepv mieszczącej 33 palety. Pojazdy te poruszać się będą po nastepuiacych drogach:

- Leszno: DK36, E261,

- Łódź: DK36, DK25, DK12, E67, DK14,

- Gdańsk: DK36, E261, E75, E77, DK89,

- Czestochowa: DK36, E261, E67, DK74, DK45, DK43,

- Kraków: DK36, E261, E67, E40, E77.

Dla jednego wozokilometra oszacowano stawke w wysokości 3,80 zł. Aby wyznaczyć koszty przeiazdu dla obecnie stosowanych pojazdów cięzarowych jak i dla proponowanych poiazdów ponadnormatywnych, uwzgledniono liczbe kilometrów iaka dzieli poszczególne oddziały. Koszty przewozu dla obu typów pojazdów przedstawiono kolejno w tabeli 3 .

Tab. 3 Koszt przewozu dwoma pojazdami standardowymi oraz EMS.

\begin{tabular}{|l|c|c|}
\hline Oddzial & $\begin{array}{c}\text { Koszt przewozu } \\
\text { (standardowe) }\end{array}$ & $\begin{array}{c}\text { Koszt przewozu } \\
\text { (EMS) }\end{array}$ \\
\hline Leszno & $230.54 \mathrm{zl}$ & $149.47 \mathrm{zł}$ \\
\hline Łódź & $1239.80 \mathrm{zl}$ & $834.80 \mathrm{zł}$ \\
\hline Gdańsk & $2317.40 \mathrm{zl}$ & $1841.47 \mathrm{zł}$ \\
\hline Częstochowa & $1332.68 \mathrm{zl}$ & $988.18 \mathrm{zł}$ \\
\hline Kraków & $2190.62 \mathrm{zl}$ & $1400.41 \mathrm{zl}$ \\
\hline
\end{tabular}

Dla poszczególnych oddziałów wyliczono średnią wartość paleto/kilometra (tabela 4). Obliczeń dokonano korzystając ze zależności:

$$
\mathrm{Kp} / \mathrm{Lk} / \mathrm{Lp}=\mathrm{Pk}
$$

gdzie: $\mathrm{Kp}-$ koszt przewozu danej liczby palet,

Lk - liczba kilometrów pomiędzy oddziałami,

Lp - liczba transportowanych palet,

$\mathrm{Pk}$ - wartość paleto/kilometra. 
Tab. 4 Średnie wartości paleto/kilometra na poszczególnych trasach.

\begin{tabular}{|l|c|c|}
\hline Oddzial & $\begin{array}{c}\text { Standardowe pojazdy } \\
\text { ciężarowe }\end{array}$ & EMS \\
\hline Leszno & $0.124 \mathrm{zł}$ & $0.080 \mathrm{zł}$ \\
\hline Łódź & $0.137 \mathrm{zł}$ & $0.089 \mathrm{zl}$ \\
\hline Gdańsk & $0.119 \mathrm{zł}$ & $0.083 \mathrm{zl}$ \\
\hline Częstochowa & $0.114 \mathrm{zl}$ & $0.075 \mathrm{zl}$ \\
\hline Kraków & $0.144 \mathrm{zl}$ & $0.092 \mathrm{zl}$ \\
\hline
\end{tabular}

Koszt przewozu jednej palety między oddziałami zamieszczono w tabeli 5.

Tab. 5 Koszt transportu jednej palety.

\begin{tabular}{|l|c|c|}
\hline Oddzial & $\begin{array}{c}\text { Standardowe pojazdy } \\
\text { ciężarowe }\end{array}$ & EMS \\
\hline Leszno & $4.70 \mathrm{zl}$ & $3.05 \mathrm{zł}$ \\
\hline Łódź & $28.18 \mathrm{zł}$ & $18.97 \mathrm{zł}$ \\
\hline Gdańsk & $45.44 \mathrm{zł}$ & $36.11 \mathrm{zł}$ \\
\hline Częstochowa & $25.63 \mathrm{zł}$ & $19.00 \mathrm{zł}$ \\
\hline Kraków & $48.68 \mathrm{zł}$ & $31.12 \mathrm{zł}$ \\
\hline
\end{tabular}

Analizowane przedsiębiorstwo wysyła towary systematycznie przez 5 dni w tygodniu. Koszty transportu w okresie tygodniowym, miesięcznym i kwartalnym przedstawiono w tabelach 6 oraz 7 a wyniki w postaci graficznej zobrazowano na rysunku 3.

Tab. 6 Koszty transportu zestawem standardowym w różnych okresach czasu.

\begin{tabular}{|l|c|c|c|}
\hline Oddzial & Tydzień & Miesiąc & Kwartal \\
\hline Leszno & $1152.70 \mathrm{zł}$ & $4610.80 \mathrm{zl}$ & $13832.40 \mathrm{zl}$ \\
\hline Łódź & $6199 \mathrm{zł}$ & $24796 \mathrm{zł}$ & $73488 \mathrm{zł}$ \\
\hline Gdańsk & $11587 \mathrm{zł}$ & $46348 \mathrm{zl}$ & $139044 \mathrm{zl}$ \\
\hline Częstochowa & $6663.40 \mathrm{zł}$ & $26653.60 \mathrm{zl}$ & $79960.80 \mathrm{zl}$ \\
\hline Kraków & $10953.10 \mathrm{zł}$ & $43812.40 \mathrm{zł}$ & $131437.20 \mathrm{zl}$ \\
\hline Razem & $36555.20 \mathrm{zł}$ & $146220.80 \mathrm{zł}$ & $438662.40 \mathrm{zł}$ \\
\hline
\end{tabular}

Tab. 7 Koszty transportu pojazdem EMS w różnych okresach czasu.

\begin{tabular}{|l|c|c|c|}
\hline Oddzial & Tydzień & Miesiąc & Kwartal \\
\hline Leszno & $747.35 \mathrm{zł}$ & $2989.40 \mathrm{zł}$ & $8968.20 \mathrm{zł}$ \\
\hline Łódź & $4174 \mathrm{zł}$ & $16696 \mathrm{zł}$ & $50088 \mathrm{zł}$ \\
\hline Gdańsk & $9207.35 \mathrm{zł}$ & $36829.40 \mathrm{zł}$ & $110488.20 \mathrm{zł}$ \\
\hline Częstochowa & $4940.90 \mathrm{zł}$ & $19763.60 \mathrm{zl}$ & $59290.80 \mathrm{zl}$ \\
\hline Kraków & $7002.05 \mathrm{zł}$ & $28008.20 \mathrm{zł}$ & $84024.60 \mathrm{zł}$ \\
\hline Razem & $26071.65 \mathrm{zł}$ & $104286.60 \mathrm{zl}$ & $312859.80 \mathrm{zł}$ \\
\hline Oszczędność & $10483.55 \mathrm{zł}$ & $41934.20 \mathrm{zł}$ & $125802.60 \mathrm{zł}$ \\
\hline
\end{tabular}


Implementation of modular trucks into road transport

Koncepcja wdrożenia zespołów modułowych $w$ transporcie drogowym

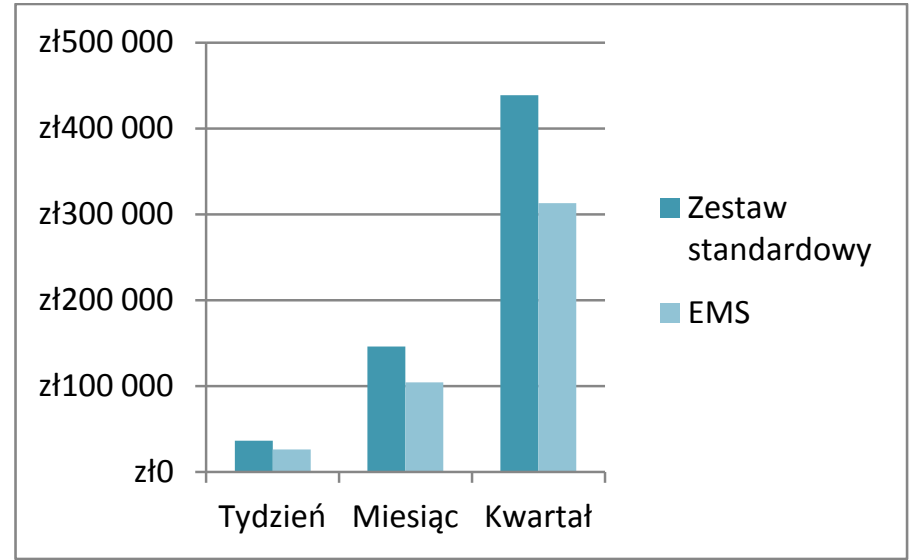

Rys. 3 Wykres kosztów transportu przez EMS i zestawy standardowe $w$ różnych okresach czasu

Analizując powyższe wyniki zauważyć można, że wdrożenie zespołów modułowych w omawianej firmie transportowej przynosi oszczędności w kwotach:

- 10483.55 zł za przewóz przesyłek w ciągu jednego tygodnia,

- 41934.20 zł za przewóz przesyłek w ciągu jednego miesiąca,

- 125802.60 zł za przewóz przesyłek w ciągu kwartału.

Zasugerowane zmiany zmniejszają koszty przewozu o $28.7 \%$.

\section{Podsumowanie}

Postępujący i przewidywany wzrost pracy przewozowej realizowanej transportem drogowym, konieczny dla gospodarczego rozwoju społeczeństwa, okupiony jest wzrostem m.in.: emisji hałasu, emisji spalin, zatłoczenia ulic oraz zagrożeń drogowymi wypadkami. Te negatywne zjawiska, które towarzyszą rozwojowi można oraz trzeba minimalizować. Koncepcja modułowa jest rozwiązaniem pozwalającym zapobiec lub ograniczyć te zjawiska. Mniejsza liczba pojazdów potrzebnych do zrealizowania danego zadania transportowego zmniejsza ryzyko zagrożeń wypadkowych, zmniejsza zatłoczenie dróg, a także obniża zużycie paliwa oraz emisję spalin do atmosfery.

Przeprowadzona analiza polskiej infrastruktury drogowej wykazała, że zespoły modułowe będą mogły zostać dopuszczone do ruchu po autostradach, drogach ekspresowych i wybranych drogach głównych. W przyszłości zaleca się zmienić wymagania dotyczące projektowania oraz wykonania infrastruktury drogowej, aby były odpowiednio dostosowane do zwiększonych wymiarów pojazdów.

Na przykładzie analizowanym w opracowaniu, można jednoznacznie stwierdzić, że zastąpienie standardowych pojazdów ciężarowych zestawami modułowymi typu EMS przynosi wymierne korzyści finansowe, ogranicza liczbę eksploatowanych pojazdów a tym samym kierowców, nie obniża poziomu bezpieczeństwa na drogach oraz relatywnie w mniejszym stopniu negatywnie oddziałuje na środowisko naturalne. 


\section{References}

[1] Akerman I., Jonsson R., European Modular System for road freight transport experiences and possibilities, Rapport 2007:2E, Sztokholm 2007.

[2] Błajda Ł., Analiza i ocena celowości wdrożenia drogowych zespołów modułowych w Polsce.

[3] Lińčák N., Olejnik K., Woźniak G., Propozycje i ocena możliwości zwiększenia rzeczywistej pracy przewozowej środków transportu drogowego, Motor Transport Institute, Warszawa 2012.

[4] Lumsden K., Truck Masses and Dimensions - Impact on Transport Efficiency, Department of Logistics and Transportation, Chalmers University of Tehchnology, Gothenburg 2004.

[5] Milewski D., Wiśnicki B., Wpływ kosztów eksploatacji wielkogabarytowych zestawów drogowych na rynek transportowy w Polsce, Zeszyty Naukowe Uniwersytetu Szczecińskiego. Problemy Transportu i Logistyki, 26/2014.

[6] Muślewski Ł., Lewalski M., Woropay M., Analysis and evaluation of application of car modular systems in polish road transport, Journal of Kones, 22(4)/2015.

[7] Poliński J., Konkurencja pociągów drogowych dla transportu kolejowego w Europie, Przegląd Komunikacyjny, 5/2014.

[8] Raczyński J: Wizja megaciężarówek - kolejowe przewozy towarowe wobec kolejnych zagrożeń, Rynek Kolejowy, 10/2007.

[9] Wiśnicki B., Galor W., Uwarunkowania przewozu ładunków pojazdami niestandardowymi w Europie, Logistyka, 2/2010.

[10] Załoga E., Milewski D., Kwarciński T., Wpływ planowanej przez Komisję Europejską zmiany dyrektywy rady 96/53/we z dnia 25 lipca $1996 \mathrm{r}$. ustanawiająca dla niektórych pojazdów drogowych poruszających się na terytorium wspólnoty maksymalne dopuszczalne wymiary w ruchu krajowym i międzynarodowym oraz maksymalne dopuszczalne obciążenia w ruchu międzynarodowym na sektor transportu w Polsce. Ekspertyza, Szczecin 2012.

[11] Longer and Heavier Vehicles in the Netherlands. Facts, figures and experiences in the period 1995-2010, Ministry of Transport, 2010.

[12] Rozporządzenie Ministra Transportu i Gospodarki Morskiej z dnia 2 marca 1999 r. w sprawie warunków technicznych, jakim powinny odpowiadać drogi publiczne i ich usytuowanie, (Dziennik Ustaw. z 1999 r., Nr 43, poz. 430).

[13] http://www.whitlockbullbars.com.au

[14] http://www.smh.com.au

[15] http://www.krone-trailer.com

[16] http://www.wikiwand.com

[17] http://upload.wikimedia.org

[18] http://www.verkehrsrundschau.de

[19] http://h-a.d-cd.net

[20] http://www.marcotran.com

[21] http://www3.picturepush.com 
Implementation of modular trucks into road transport

Koncepcja wdrożenia zespołów modułowych $w$ transporcie drogowym

[22] http://www.nhvr.gov.au

[23] http://www.smart-trucking.com

[24] http://www.truckandtrailer.ca

[25] http://www.mexicotrucker.com

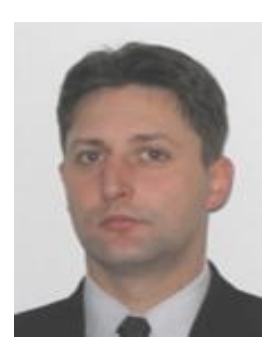

Prof. nadzw. dr hab. inż. Lukasz Muślewski jest kierownikiem Zaktadu Eksploatacji $i$ Transportu na Wydziale Inżynierii Mechanicznej, Uniwersytetu Technologiczno - Przyrodniczego im. J.J. Śniadeckich w Bydgoszczy. W pracy naukowej zajmuje się zagadnieniami jakości działania złożonych systemów eksploatacji a $w$ szczególności systemów transportowych. Realizuje badania z zakresu niezawodności, bezpieczeństwa, efektywności $i$ ekologiczności systemów socjotechnicznych, w których na jakość ich działania maja wptyw operatorzy, sterowane przez nich obiekty techniczne oraz czynniki oddziałujacych z otoczenia (Udziat 50\%).

Dr inz. Bogdan Landowski pracuje w Zaktadzie Transportu

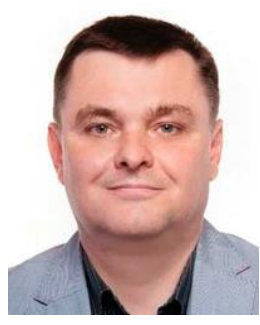
i Eksploatacji na Wydziale Inżynierii Mechanicznej Uniwersytetu Technologiczno-Przyrodniczego $w$ Bydgoszczy. W pracy naukowej zajmuje się problemami dotyczacymi efektywności zlożonych systemów eksploatacji oraz modelowania procesów $i$ systemów eksploatacji. Tematyka badawcza obejmuje zastosowanie teorii decyzyjnych procesów Markowa do matematycznego modelowania procesów eksploatacji. Prowadzi badania $w$ zakresie modelowania numerycznego procesów i systemów eksploatacji (Udziat 30\%.

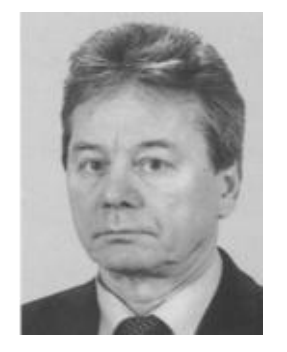

Prof. dr hab. inz. Maciej Woropay, w pracy naukowej zajmuje się problemami dotyczacymi teorii systemów, teorii niezawodności $i$ bezpieczeństwa oraz sterowania procesami eksploatacji $w$ złożonych systemach biotechnicznych, a w szczególności sterowaniem tymi procesami w systemach transportu miejskiego. Jest autorem ponad 160 prac naukowych opublikowanych $w$ kraju $i$ za granica, a także podręczników $i$ skryptów akademickich, promotorem ponad 180 prac magisterskich i inżynierskich oraz rozpraw doktorskich (Udziat 10\%).

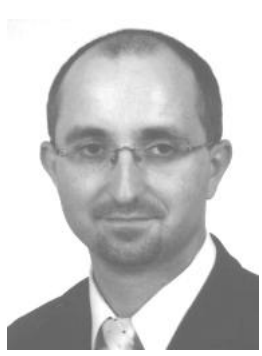

Dr hab. inz. Klaudiusz Migawa, prof. nadzw. UTP, pracownik Wydziału Inżynierii Mechanicznej Uniwersytetu TechnologicznoPrzyrodniczego w Bydgoszczy. W pracy naukowej zajmuje sie problematyka oceny $i$ sterowania poziomem efektywności, niezawodności, gotowości oraz bezpieczeństwa złożonych systemów eksploatacji obiektów technicznych. Autor prac naukowych $z$ zakresu modelowania systemów $i$ procesów eksploatacji środków transportu (Udziat 10\%). 